\title{
Yağışların tarım alanlarında sebep olduğu göllenmelerin Sentinel-1 uydu görüntüleri ile analizi
}

\author{
Salih Babagiray ${ }^{* *}$, Kaan Kalkan² ${ }^{2}$ \\ ${ }^{1}$ Tarım ve Orman Bakanlığı, Su Yönetimi Genel Müdürlüğü-Taşkın Tahmini ve Erken Uyarı Merkezi, Yenimahalle, Ankara, Türkiye \\ ${ }^{2}$ Türkiye Bilimsel ve Teknolojik Araştırma Kurumu Uzay Teknolojileri Araştırma Enstitüsü, Çankaya, Ankara, Türkiye
}

Öz: Bu çalışmada, 24.12.2019 - 08.01.2020 tarihleri arasında Adana ilinde aralıklarla etkili olan yağlşlar çalışma alanı içerisinde ve çevresinde bulunan 18 adet Otomatik Meteoroloji Gözlem İstasyonundan alınan günlük toplam yağlş verileri ile birlikte analiz edilmiştir. Çalışma alanı, Adana ili; Seyhan, Çukurova, Sarıçam ve Yüreğir merkez ilçeleri ile Karataş ilçesinden oluşmaktadır. Bu yağlı̧lardan kaynaklı bahsi geçen ilçelerdeki göllenmeler, Sentinel-1 uydu görüntüleri kullanılarak analiz edilmiştir. Uydu görüntüsü olarak; yağlşlardan önce (09.12.2019), yağlşlar sırasında (02.01.2020) ve sonunda (08.01.2020) olmak üzere üç farklı görüntü kullanılmıştır. Ayrıca, bölgedeki toprak neminin yağışlar ile değişimi de irdelenmiştir. Toprak nemi veri kaynağı olarak Soil Moisture Active Passive (SMAP) kullanılmıştır. Çalışmada kot, eğim, toprak yapısl, toprak nemi ve yağışlar incelenerek oluşan göllenmelerin sebepleri araştırılmıştır. Yağışların toprak nemini 2 katına kadar yükselttiği ve bu artışın, toprağın sızma kapasitesini azalttığı için göllenmeye yardımcı olduğu düşünülmektedir. Yapılan analizler doğrultusunda göllenmenin yoğun olduğu bölgelerde çoğunlukla hidrolojik toprak grubunun " $D$ ”, eğimin ise \%1'in altında olduğu tespit edilmiştir.

Anahtar Sözcükler: Adana, Sentinel-1 SAR, SMAP, Hidrolojik toprak grubu, Toprak nemi, Taşkın

\section{Analysis of pondings caused by rainfall in agricultural areas by using Sentinel-1 satellite images}

\begin{abstract}
In this study, the rainfall that was effective between 24.12.2019 - 08.01.2020 in Adana was analyzed together with the daily total precipitation data from 18 Automatic Meteorological Observation Stations located within and around the study area. The study area consists of the central districts of Adana province; Seyhan, Çukurova, Sarlçam and Yüreğir and the district of Karataş. The pondings in the districts mentioned due to these precipitations were analyzed using Sentinel-1 satellite images. Three different images were used as a satellite image in the study; before the precipitation (09.12.2019), during the precipitation (02.01.2020) and at the end of the precipitation (08.01.2020). In addition, the change of soil moisture in the region with precipitation was also examined. Soil Moisture Active Passive (SMAP) was used as a soil moisture data source. In the study; the effects of altitude, slope, soil structure, soil moisture and precipitation on pondings were investigated. Precipitation increased soil moisture up to 2 times, and therefore it is thought that it helped pondings due to the decrease of leakage capacity of the soil. According to the analyses, in regions where ponding is intense; it has been mostly determined that the hydrological soil group is " $D$ " and the slope is below $1 \%$.
\end{abstract}

Keywords: Adana, Sentinel-1 SAR, SMAP, Hydrologic soil group, Soil moisture, Flood 


\section{Giriş}

Şiddetli yağışlar, yerleşim yerlerindeki hayatı olumsuz etkilemekle birlikte zaman zaman tarım alanlarına da zarar verebilmektedir. Yağışların ani olarak yere inmesi veya uzun süreli devam etmesi toprağı doyurmakta ve yüzey akışını artırmaktadır. Yüzey akışının hızlı artması, derelerin taşmasına sebep olabileceği gibi, topoğrafik şartlara ve toprak yapısına bağlı olarak suyun, dere yataklarına ulaşmadan tarım alanlarında göllenmesine de sebep olabilmektedir.

Eğimi düşük tarım alanlarında fazla suyu tahliye etmek için yapılan drenaj kanalları, proje ekonomisi ve işletme-bakım faaliyetleri göz önünde bulundurularak projelendirilirler. Bu nedenle, kanalların taşkın sularını tahliye kapasitesi sınırlı olup, ardışık ve şiddetli yağışlar sonucunda geniş alanlar su ile kaplanmakta ve önemli oranda tarımsal zararlara sebep olabilmektedir (Akgül \& Çetin, 2019).

Su ile kaplı alanların haritalanması ve izlenmesinde, uzaktan algılama tekniklerinin başarılı bir araç olduğu son yıllarda yapılan çalışmalarla kanıtlanmıştır. Uydudan uzaktan algılama tekniklerinin özellikle büyük coğrafi alanlar için kullanımı, geleneksel haritalama tekniklerine kıyasla genellikle daha az maliyetlidir ve sonuçlar daha hızlı elde edilebilmektedir (Kaplan \& Avdan, 2018a).

Sentetik Açıklıklı Radar (Synthetic Aperture Radar, SAR) uydu görüntüleri bulutlu ortamlarda dahi görüntü sağlayarak optik görüntülere göre avantaj sağlamaktadır (Smith, 1997). Ayrıca Sentinel-1 SAR görüntüleri, sis veya dumandan da etkilenmez ve hem gece hem de gündüz veri sağlayabilmektedir (Carreño Conde \& De Mata Munoz, 2019).

SAR görüntüleri kullanılarak taşkın alanlarının belirlenmesinde, özellikle şehir içerisindeki gölgeli alanların, düz su yüzeylerinde olduğu gibi geri saçılma yapamaması sebebiyle bazı zorluklar yaşanmaktadır. Çok sayıda beton, çelik vb. yapılardan oluşan kentsel alanlarda yaşanan bu geri saçılma problemi sebebiyle, bu alanlarda SAR görüntülerini kullanarak taşkınları tespit etmek oldukça zordur. Buna ek olarak, Sentinel-1 SAR görüntülerinin bize sağladığı mekânsal çözünürlük (10 x 10 m) cadde, bina vb. yapıları ayırmak için çok da uygun değildir. Ancak bu görüntülerle, açık alanlarda çok daha sorunsuz analizler yapılabilmektedir (Tavus, Kocaman, Gökçeoğlu, \& Nefeslioğlu, 2018).

Çalışmada analiz edilen görüntülerin temin edildiği Sentinel-1 SAR uydusunun ana görevleri arasında; su kaynaklarının, toprakların ve tarım alanlarının izlenmesi, doğal afet durumunda acil durum haritalarının üretilmesi yer almaktadır. Söz konusu analizler için, SAR uydusunun sahip olduğu farklı polarizasyon modları (yatay, Horizontal-H; dikey, Vertical-V olmak üzere HH, VV, HH + VH veya VV + VH) kullanılabilmektedir. SAR verileri kullanılarak taşkın alanı tespitinde, uydu üzerinde bulunan alıcı ve verici antenlerinin ikisinin de dikey konumlandığı VV modu, diğer polarizasyon modlarına göre daha iyi sonuç vermektedir (Akgül, 2018). Manjusree, Kumar, Bhatt, Rao ve Bhanumurty (2012)'de de yüzey pürüzlülüğüne ve taşkın alanlarına daha duyarlı olan VV modu kullanılmıştır.

Teknolojide yaşanan gelişmeler sayesinde, uydu görüntülerinin zamansal olarak sıklığı ve çözünürlüğü artmış ve bu da birçok alanda daha detaylı analizler yapmaya firsat sağlamıştır. Yağış öncesi ve sonrasında elde edilen uydu görüntülerinin işlenmesi ile hangi bölgelerin ve ne kadarlık bir alanın sular altında kaldığı analiz edilebilmektedir. Bu çalışmada da; 24.12 .2019 08.01.2020 tarihleri arasında Adana ili ve civarında aralıklarla etkili olan ve birçok bölgede göllenmelere sebep olan yağışları incelemek için, 09.12.2019, 02.01.2020 ve 08.01.2020 tarihli Sentinel-1 SAR uydu görüntülerinden faydalanılmıştır. Yağışlardan kaynaklı göllenmeler, noktasal olarak alınan Otomatik Meteoroloji Gözlem İstasyonu (OMGİ) verilerinin alansallaştırılması ile elde edilen alansal yağışlar ve bahsi geçen uydu görüntüleri kullanılarak analiz edilmiştir. 
Özellikle kısmen düz alanlarda ve nehre yakın bölgelerde, şiddetli yağışlardan kaynaklı lokal göllenmeler ile nehrin yatağından taşması sonucu suyla kaplanan alanların ayırt edilebilmesi oldukça zordur. Bu sebeple, çalışma alanı içerisinde yer alan Seyhan ve Ceyhan Nehirlerinin hidrolojik ve hidrolik taşkın analizleri yapılmamış ve elde edilen su basma alanlarının tamamının şiddetli yağışlardan kaynaklanan göllenmeler olduğu kabulü ile analizler yapılmıştır. Benzer bir çalışmada da Akgül ve Çetin (2019), Aşağı Seyhan Ovası'nda 15-19 Ocak 2019 tarihlerindeki ardışık yağışları ve meydana gelen taşkınlardan etkilenen tarım alanlarını Sentinel 1, Sentinel 2 ve Landsat 8 uydu görüntüleri kullanarak incelemiştir. Burada diğer çalışmalardan farklı olarak, Sentinel-1 SAR uydu görüntüleri ile toprak nemi değişimi ve toprak yapısı da ayrıca irdelenmiştir.

Toprak nemi, yer ve atmosfer arasındaki su ve enerji döngüsünün anlaşılmasında çok önemli bir rol oynamaktadır. Toprak nemi değerlerinin doğru ve güvenilir bir şekilde elde edilmesi; hava tahmini, kuraklık analizi, taşkın tahmini ve orman yangınları gibi birçok alanda kullanılabilmesine olanak sağlar (Bulut vd., 2019). Yüksek zamansal çözünürlüğe sahip toprak nemi verileri; taşkınları izlemek, tahmin etmek ve sebep olduğu zararların boyutunu anlamak maksatlarıyla kullanılabilmektedir (Rahman vd., 2019). Analizlerde kullanılan toprak nemi verilerinin sağlandığ Soil Moisture Active Passive (SMAP); yeryüzüne ait toprak nemi ve donma-çözülme durumları ile ilgili verileri sağlamak için tasarlanmış ve dünya genelinde gözlem yapabilen, uzay tabanlı bir projedir (Entekhabi vd., 2010). Amerika Birleşik Devletleri Ulusal Havacılık ve Uzay Dairesi tarafından geliştirilen SMAP, taşkın ve kuraklık çalışmalarında kullanıldığı gibi, daha farklı birçok alanda da kullanılabilmektedir. Burada da; SMAP toprak nemi verilerinin, gerçekleşen yağışlarla değişimi ve bu değişimin göllenmelere olan etkisi görsel olarak incelenmiş̧ir.

Yağışlarla yeryüzüne inen su, yerçekimi ve kapiler kuvvet etkisiyle toprak yüzeyindeki boşluk ve çatlaklardan içeri sızar. Buradaki sızma hızı; toprak yapısını oluşturan kum, silt ve kil içeriğine ve ayrıca toprağın drenaj özelliklerine göre belirlenmiş hidrolojik toprak gruplarına bağlıdır (Usul, 2008). Sızma, yüzey akışını etkileyen en önemli unsurlardandır (Pitt Chen, Clark, Swenson, \& Ong, 2008). Örneğin; sızma hızının yavaş olduğu bölgelerde, eğim durumuna da bağlı olarak yüzey akışı oldukça yavaştır veya hiç gerçekleşmez. Yer altına sızamayan ve yüzey akışına da geçemeyen sular yüzeyde birikerek küçük su birikintileri ve gölcükleri oluşturur. Bu çalışmada da; inceleme alanına ait hidrolojik toprak grupları belirlenerek, göllenmelerin hangi bölgelerde daha yoğun oluştuğu eğim durumu ile birlikte analiz edilmiştir.

\section{2. Çalışma Alanı}

Yağışlardan kaynaklı göllenmeler, özellikle Yüreğir ve Karataş ilçe sınırları içerisindeki tarım alanlarında ve Seyhan ilçesinde de kısmen gözlenmiştir. Havzanın kuzeyinde bulunan dağlık kısımdaki yağış etkisinin de görülebilmesi için, Çukurova ve Sarıçam ilçeleri de çalışmaya dâhil edilmiştir. Sonuç olarak; Adana ili; Seyhan, Çukurova, Sarıçam ve Yüreğir Merkez ilçeleri ile Karataş ilçesi sınırları, çalışma alanı olarak belirlenmiştir. Söz konusu çalışma alanı sınırları Şekil 1'de görülmektedir. 


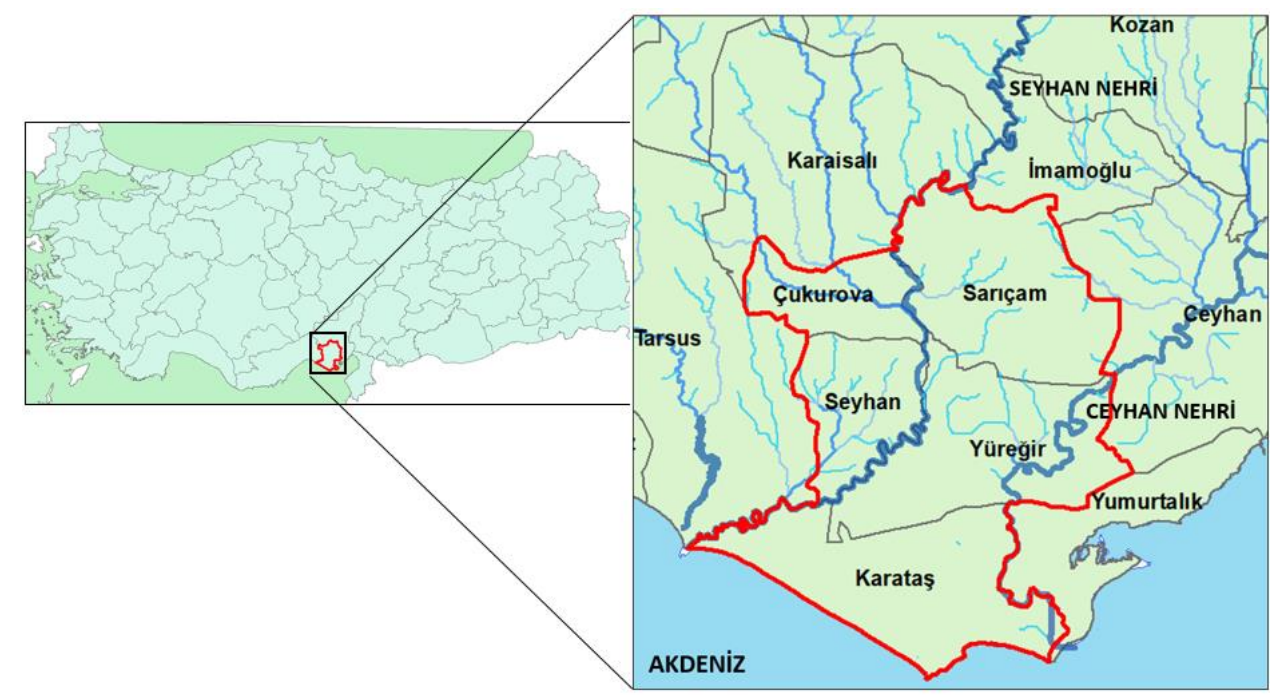

Şekil 1: Çalışma alanı

Çalışma kapsamında üretilen sayısal yükseklik modeli (SYM), Harita Genel Müdürlüğü’nden alınan 10 m çözünürlüklü eş yükselti eğrileri kullanılarak elde edilmiştir (Şekil 2a). Çalışma alanının güney kısmı, Seyhan ve Ceyhan Nehirlerinin yıllar boyunca taşıdığı alüvyonlar sebebiyle oldukça düz ve verimli arazilerden oluşmaktadır. Ortalama eğim \%6 olmasına rağmen özellikle dağllk kısmın güneyindeki bölgede $\% 0$ eğime kadar düşen yerler mevcuttur (Şekil 2b).
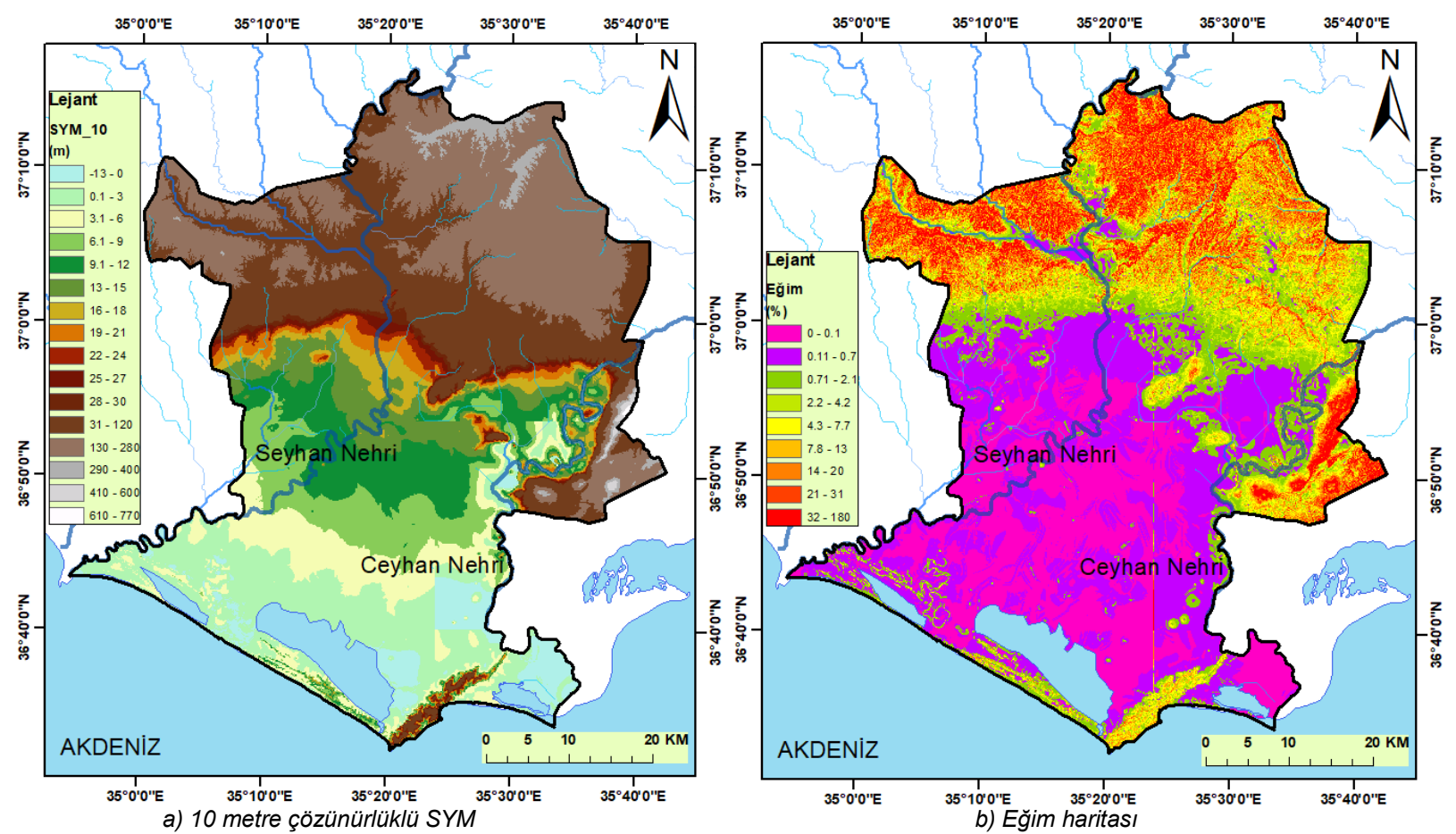

Şekil 2: Çalışma alanı SYM ve eğim haritaları

Çalışma alanı içeresinde Seyhan ve Çatalan Barajları ile birlikte birkaç küçük gölet bulunmaktadır. Ayrıca güneyde üç adet doğal göl mevcuttur (Şekil 3). Oldukça verimli arazilerin yer aldığı ve Çukurova olarak bilinen bölgeyi Seyhan ve Ceyhan Nehirleri beslemektedir. 


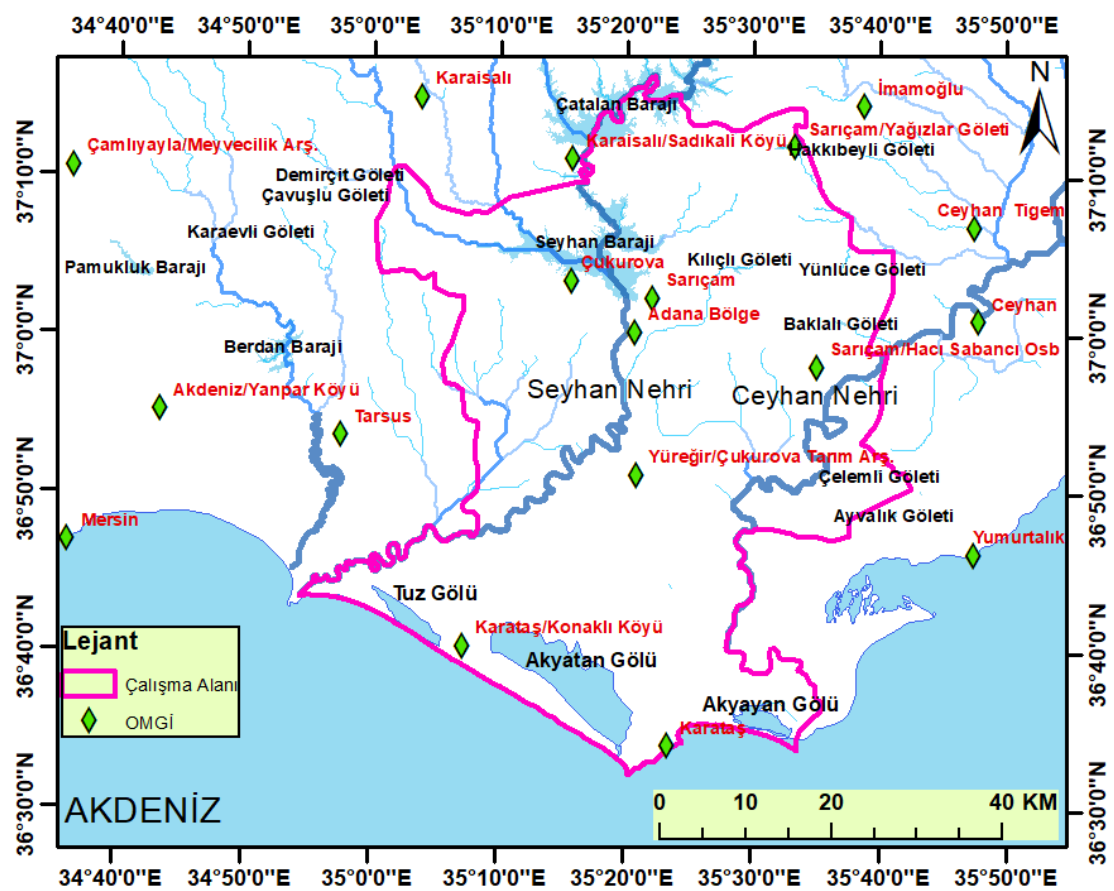

Şekil 3: Çalışma alanı içerisinde bulunan baraj, göl, akarsular ve OMGi konumları

\section{Yağış Analizleri}

Yağışlar, 18 adet OMGİ'nin günlük toplam değerleri ile analiz edilmiştir. Söz konusu OMGİ konumları Şekil 3'te verilmiştir. Çalışmada kullanılan istasyonlar ve 24.12.2019 - 08.01.2020 tarihleri arasında istasyonlarda ölçülen 16 günlük değerler Tablo 1'de verilmiştir (06:00 UTC). En fazla yağış görülen istasyon Yüreğir/Çukurova Tarım Araştırma İstasyonu olmuş ve en yüksek yağış 24.12 .2019 tarihinde $182 \mathrm{~mm}$ olarak ölçülmüştür. 24 ve 25 Aralık 2019 tarihlerinde toplam 320 mm yağış görülmüştür. Bu istasyonun 16 gün boyunca kaydettiği toplam yağış miktarı ise 594 mm’dir.

Tablo 1: Çalışmada kullanılan OMGi'ler ve 24.12.2019 - 08.01.2020 tarihleri arasındaki OMGi ölçümleri

\section{Günler}

\begin{tabular}{|c|c|c|c|c|c|c|c|c|c|c|c|c|c|c|c|c|c|}
\hline İstasyon Adı & 24 & 25 & 26 & 27 & 28 & 29 & 30 & 31 & 1 & 2 & 3 & 4 & 5 & 6 & 7 & 8 & $\begin{array}{c}\begin{array}{c}\text { Toplam } \\
(\mathbf{m m})\end{array} \\
\end{array}$ \\
\hline Ceyhan Tigem & 53 & 107 & 46 & 1 & 0 & 3 & 9 & 4 & 0 & 0 & 3 & 8 & 0 & 0 & 10 & 10 & 256 \\
\hline Ceyhan & 53 & 131 & 60 & 8 & 0 & 3 & 12 & 8 & 0 & 0 & 5 & 9 & 0 & 0 & 14 & 17 & 319 \\
\hline Karaisalı & 65 & 62 & 37 & 11 & 0 & 5 & 36 & 45 & 0 & 0 & 4 & 22 & 0 & 0 & 52 & 73 & 411 \\
\hline Karataş & 42 & 35 & 61 & 20 & 0 & 2 & 50 & 52 & 0 & 0 & 2 & 54 & 0 & 0 & 38 & 82 & 438 \\
\hline Yumurtalık & 11 & 96 & 78 & 13 & 0 & 13 & 6 & 3 & 0 & 0 & 6 & 17 & 0 & 0 & 18 & 23 & 286 \\
\hline Adana Bölge & 92 & 147 & 24 & 12 & 0 & 3 & 29 & 23 & 0 & 0 & 4 & 15 & 0 & 0 & 28 & 67 & 444 \\
\hline Tarsus & 64 & 46 & 13 & 12 & 0 & 18 & 39 & 51 & 0 & 0 & 7 & 26 & 1 & 1 & 53 & 67 & 397 \\
\hline Mersin & 45 & 27 & 14 & 14 & 5 & 15 & 21 & 38 & 0 & 0 & 17 & 29 & 4 & 3 & 85 & 75 & 392 \\
\hline İmamoğlu & 58 & 159 & 26 & 5 & 1 & 6 & 9 & 3 & 0 & 0 & 7 & 9 & 1 & 1 & 14 & 20 & 318 \\
\hline Yüreğir/Çukurova Tarım Arş. & 182 & 138 & 26 & 18 & $\mathbf{0}$ & 2 & 34 & 37 & $\mathbf{0}$ & $\mathbf{0}$ & 3 & 29 & $\mathbf{0}$ & $\mathbf{0}$ & 40 & 84 & 594 \\
\hline Çamliyayla/Meyvecilik Arş. & 51 & 28 & 28 & 5 & 0 & 6 & 33 & 35 & 25 & 0 & 2 & 19 & 1 & 0 & 68 & 13 & 313 \\
\hline Çukurova & 89 & 100 & 29 & 11 & 0 & 2 & 35 & 29 & 0 & 0 & 0 & 19 & 0 & 6 & 21 & 71 & 411 \\
\hline Sarıçam & 84 & 158 & 24 & 9 & 0 & 2 & 25 & 20 & 0 & 0 & 5 & 16 & 0 & 0 & 24 & 68 & 436 \\
\hline Sarıçam/Hacı Sabancı Osb. & 129 & 91 & 29 & 19 & 0 & 2 & 14 & 11 & 0 & 0 & 3 & 10 & 0 & 0 & 21 & 41 & 370 \\
\hline Sarıçam/Yağızlar Göleti & 80 & 167 & 23 & 21 & 0 & 3 & 14 & 6 & 0 & 0 & 5 & 10 & 0 & 0 & 15 & 45 & 388 \\
\hline Karaisalı/Sadıkali Köyü & 96 & 107 & 25 & 17 & 1 & 1 & 29 & 25 & 1 & 5 & 3 & 14 & 0 & 0 & 24 & 77 & 423 \\
\hline Karataş/Konaklı Köyü & 148 & 102 & 19 & 7 & 0 & 1 & 53 & 57 & 0 & 0 & 1 & 32 & 1 & 0 & 60 & 86 & 566 \\
\hline Akdeniz/Yanpar Köyü & 38 & 29 & 17 & 8 & 0 & 8 & 24 & 32 & 1 & 0 & 3 & 21 & 8 & 1 & 74 & 56 & 319 \\
\hline
\end{tabular}


Söz konusu yağışlar, en fazla yağış ölçümü alınan Yüreğir/Çukurova Tarım Araştırma İstasyonu değerleri ile grafik halinde Şekil 4'te sunulmuştur. Buna göre; 24 ve 25 Aralık 2019 tarihlerinde 100 mm üzerinde bir yağış görülmüştür. 16 gün boyunca aralıklarla devam eden yağışlar, 8 gün 20 mm üzerine çıkmış ve 08.01.2020 tarihinde son bulmuştur.

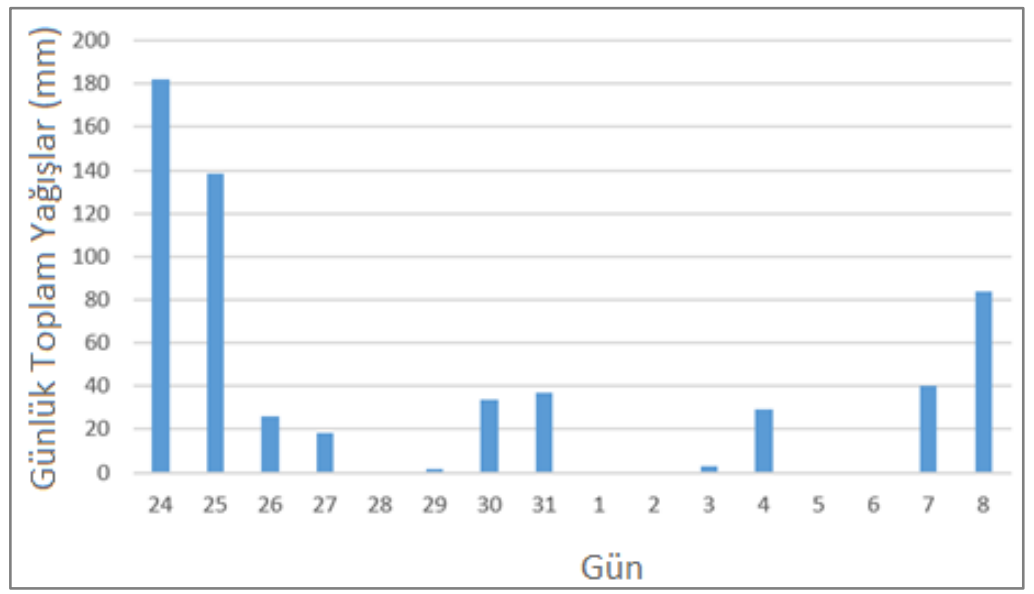

Şekil 4: Yüreğir/Çukurova Tarım Araştırma Istasyonunun ölçtüğü günlük toplam yağışlar

Ters Mesafe Ağırlıklı (Inverse Distance Weighted, IDW) enterpolasyon yöntemi; çalışma alanı içerisindeki ve/veya civarındaki bilinen verilerden, alansal yağış verilerini tahmin etmek için kullanılmaktadır (Chen \& Lui, 2012). Bu çalışmada da, OMGİ'lerden nokta olarak alınan yağış verilerini alansallaştırmak maksadıyla, hidrolojik çalışmalarda sıkça kullanılan IDW yöntemi kullanılmıştır. IDW yöntemi; ağırlığın, mesafenin tersi ile tanımlandığı ve toplamları bire eşit olacak şekilde normalize edildiği ters mesafelerin fonksiyonlarına dayanır. Mesafe arttıkça, noktasal verinin alansal veriye etki etme ağırlığı azalmaktadır (Ly, Charles, \& Degré, 2013).

Alansallaştırma 20 mm üzerinde yağış görülen; 24, 25, 26, 30 ve 31 Aralık 2019 ile 4, 7 ve 8 Ocak 2020 tarihleri için yapılmıştır (Şekil 5). Bu analiz ile gerçekleşen yağışların alansal olarak hangi bölgeleri etkilediği daha iyi anlaşılmaktadır.

24.12.2019 tarihinde Yüreğir/Çukurova Tarım Araştırma İstasyonu civarında etkili olan yağışların ertesi gün kuzeye doğru hareket ettiği görülmektedir. Sonrasında, güneyde yer alan ve eğimi düşük olan bölgede, 26, 30 ve 31 Aralık 2019 ile 4, 7 Ocak 2020 tarihlerinde 30-40 mm arasında ve son olarak da 8 Ocak 2020 tarihinde 60-85 mm arasında günlük toplam yağışlar görülmüştür. Bahsi geçen yağışlar Şekil 5'te sırasıyla; 24, 25, 26, 30 ve 31 Aralık 2019 tarihleri ile 4, 7 ve 8 Ocak 2020 tarihleri için verilmiştir. 


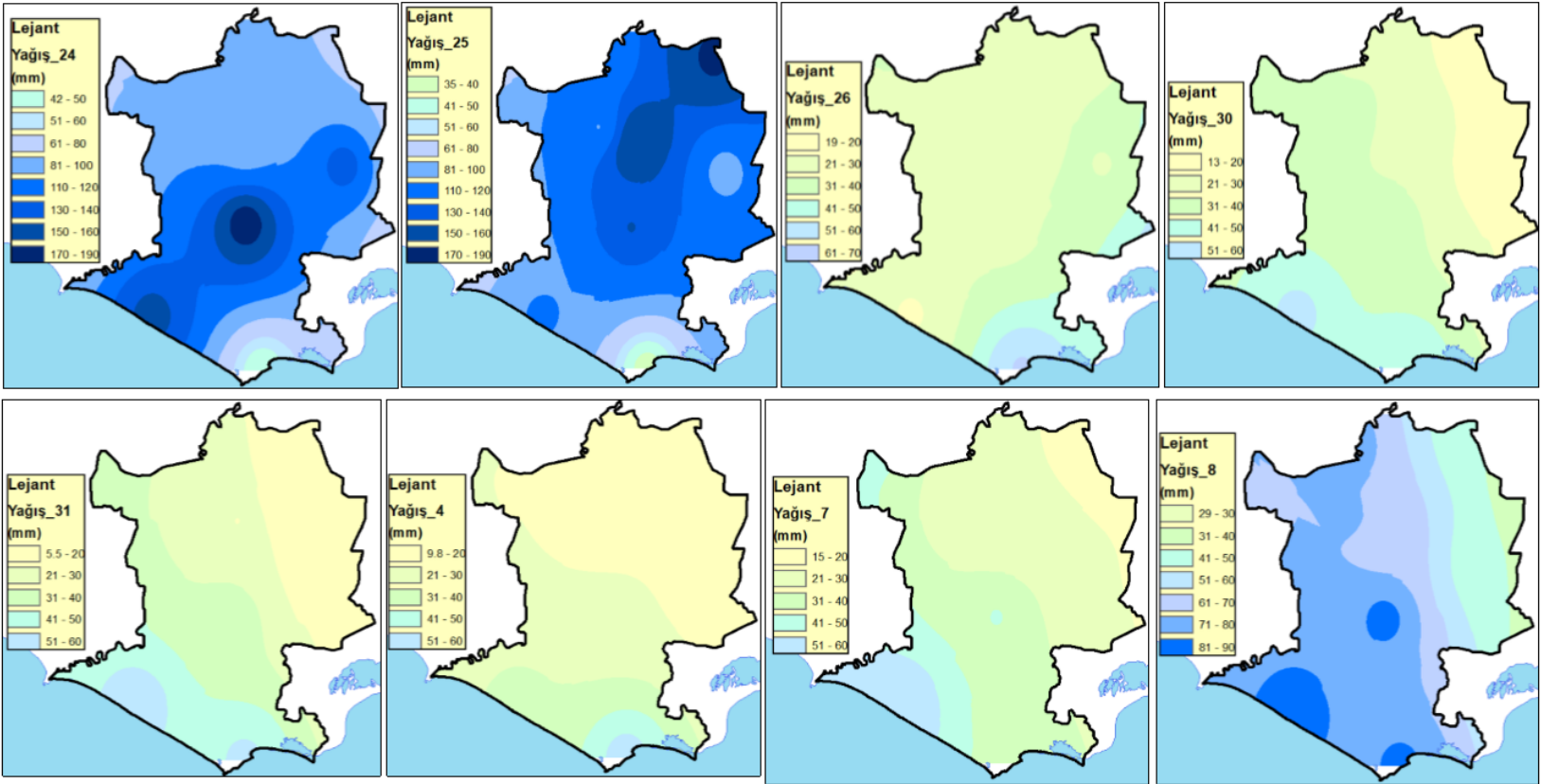

Şekil 5: 20 mm üzerindeki yağışların alansal etkisi

\section{Yağış ve Toprak Nemi İlişkisi}

Toprak nemi, bir toprak örneğindeki su miktarının ölçüsüdür. Bu su içeriği ölçüsü, birimsizdir ve oran olarak ifade edilebilir. Toprak nemi, deneyler yardımıyla hacimsel veya gravimetrik olarak elde edilebilir (URL-1). Ancak gelişen uzaktan algılama teknolojileri, bu verinin uydu görüntüleri kullanılarak da elde edilmesine olanak sağlamıştır. Bu bağlamda görevleri, küresel toprak nem içeriğini mikrodalga sensörler aracıllğıyla izlemek olan birçok özel uydu tasarlanmıştır. SMAP projesi buna örnek verilebilir.

Çalı̧̧mada kullanılan SMAP, L-bant mikrodalga radar ve radyometrik sistemlerden oluşmaktadır (Rahman vd., 2019). 3 saat aralıklarla tüm dünya genelinde elde edilebilen verilerin çözünürlüğü yaklaşık 9 km'dir (URL-2). SMAP verisinin elde edildiği radar, dünya yüzeyinden geri gelen yansımaların kalitesini ve miktarını ölçer. Bu veriler ile su miktarı için, toprağın ilk 10 cm'sine kadar yorum yapılabilir (URL-1). Çalışmanın günlük olması sebebiyle toprak nemi değerleri için, 06:00'daki (UTC) değerler günlük tek bir değer olarak alınmıştır. SMAP, ürettiği birçok verinin yanında L4_SM (üretim tipi) koduyla kullanıma sunduğu veride, "Yüzey (Surface)" ve "Kök bölgesi (Root zone)" olmak üzere iki katmanda veri bulundurmaktadır. Bu çalışmada toprağın ilk 5 cm'lik kısmını algılayan "Yüzey (surface)" verisi kullanılmıştır.

Toprak neminin yağış ile değişimi, 80 mm üzerinde günlük yağışların gerçekleştiği; 24 ve 25 Aralık 2019 ile 8 Ocak 2020 tarihleri için analiz edilmiştir. Burada analiz edilen günün öncesindeki toprak nemi, alansal yağış miktarı ve gün sonundaki toprak nemi sırasıyla bahsi geçen her gün için verilmiştir (Şekil 6). Ayrıca 16 günlük toplam yağış ve toprak nemi değişimi de Şekil 6d'de verilmiştir.

$\mathrm{Bu}$ veriler incelendiğinde özellikle 24 Aralık 2019 tarihinde gerçekleşen yağışın toprak nemini iki katına kadar artırdığı gözlenmiştir. 25 Aralık 2019 ve 8 Ocak 2020 tarihlerindeki yağışlar ise; yoğun olarak düştüğü yerlerde toprak nemini artırmıştır. 16 günlük toplam yağışlar incelendiğinde; toprak neminde iki kata kadar artışlar gözlenmiştir. 

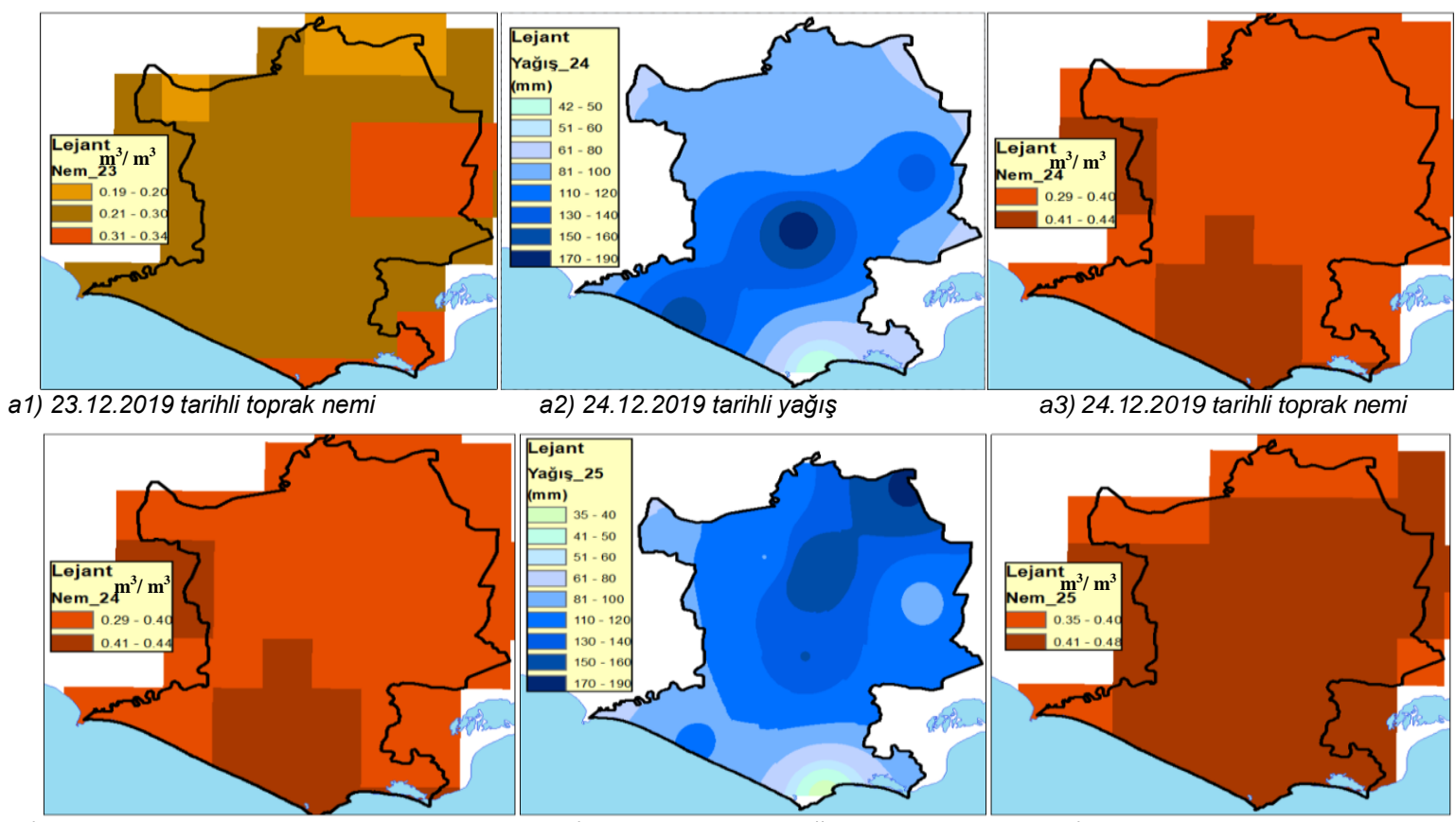

b1) 24.12 .2019 tarihli toprak nemi

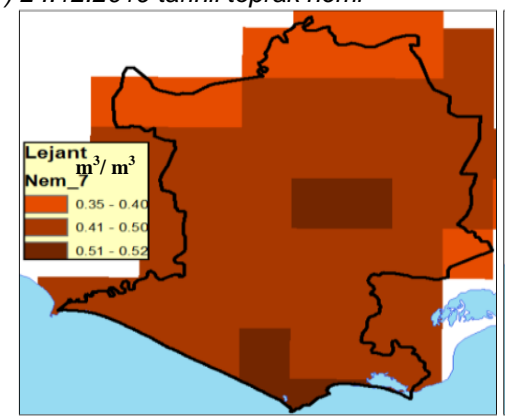

b2) 25.12.2019 tarihli yağış

b3) 25.12.2019 tarihli toprak nemi

c1) 07.01.2020 tarihli toprak nemi

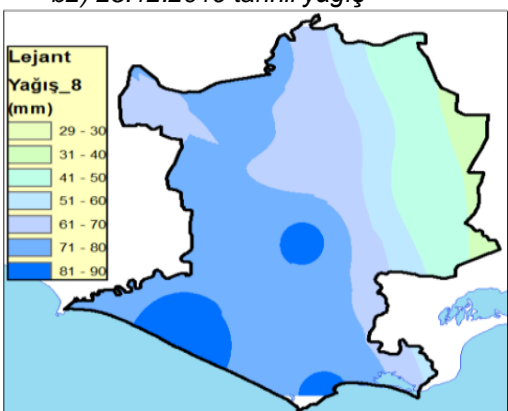

c2) 08.01.2020 tarihli yağış

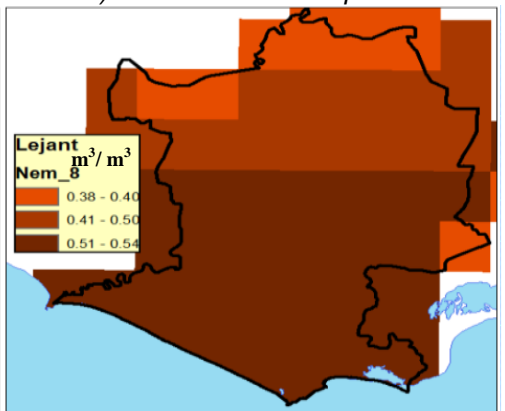

c3) 08.01.2020 tarihli toprak nemi

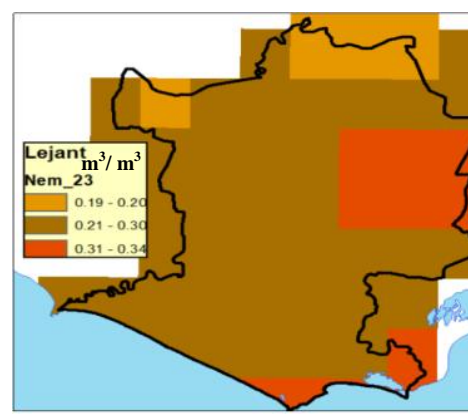

d1) 23.12.2019 tarihli toprak nemi

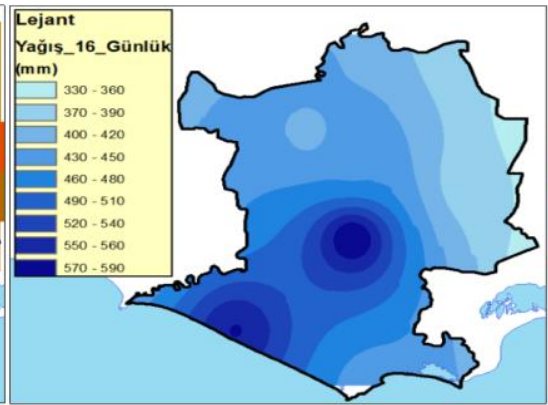

d2) 16 günlük toplam yağış

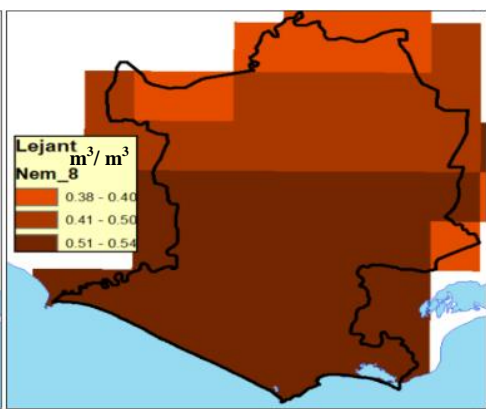

d3) 08.01.2020 tarihli toprak nemi

Şekil 6: 80 mm üzerindeki yağışların alansal etkisi

02.01.2020 ve 08.01.2020 tarihli uydu görüntülerinden elde edilen yağışlardan kaynaklı göllenmeler (bu konu Bölüm 6 ve Bölüm 7'de incelenmiştir) ile yine 02.01.2020 ve 08.01.2020 tarihli SMAP toprak nemi verileri Şekil 7'de verilmiştir. Toprak neminin gerçekleşen yağışların konumuna bağlı olarak arttı̆̆ (Şekil 6) ve bu sebeple, toprak neminin arttı̆̆ bölgelerde de göllenmelerin oluştuğu düşünülmektedir. Özellikle Şekil 7b'de, toprak neminin en yüksek (08.01.2020 tarihi için 0.51-0.54) olduğu, çalışma alanının güney kısmında çok daha fazla göllenme olduğu görülmektedir. Buradaki göllenmeler, aynı zamanda toprak yapısına da bağlıdır ancak bu konu detaylı olarak Bölüm 7'de incelenmiştir. 


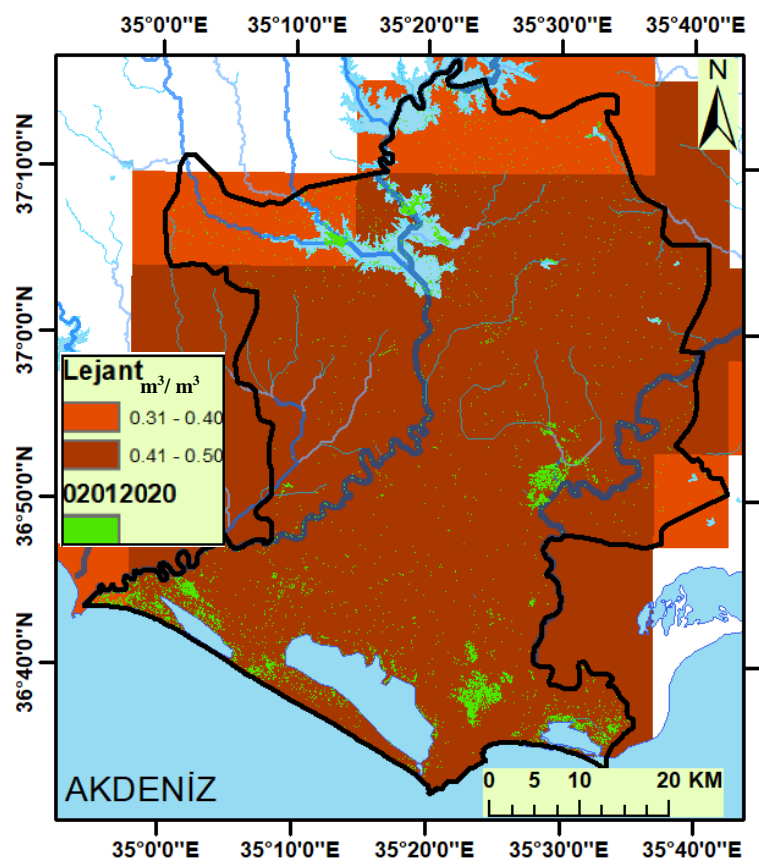

a) 02.01.2020 tarihli göllenme ve toprak nemi

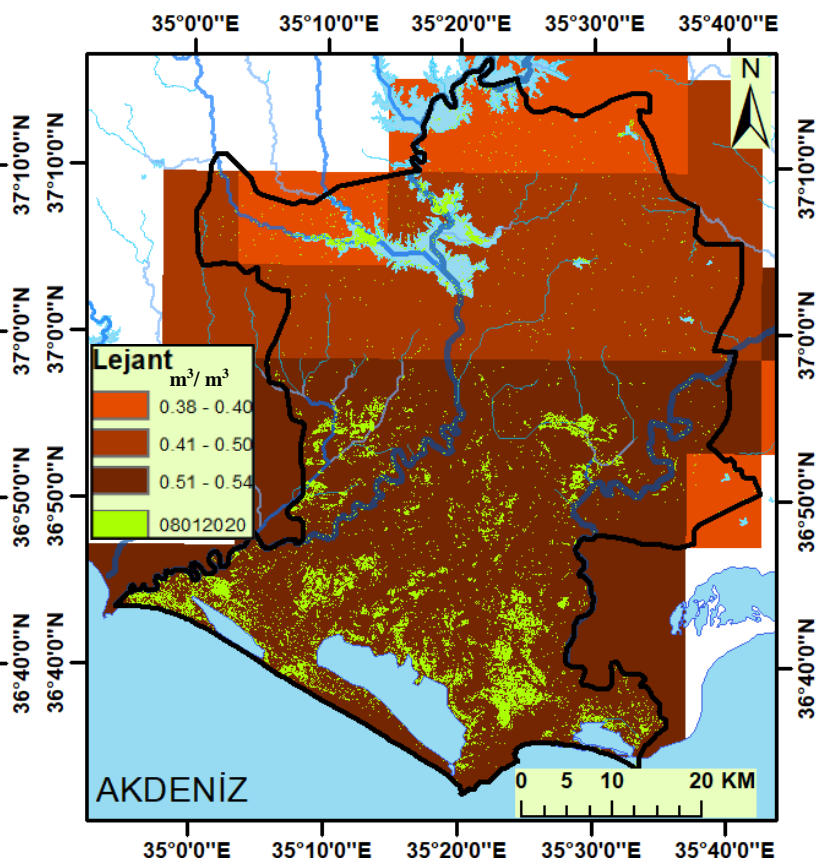

b) 08.01.2020 tarihli göllenme ve toprak nemi

Şekil 7: Uydu verisinden elde edilen göllenmeler ve toprak nemi

\section{Toprak Yapısı}

Zeminin sızma hızı azaldıkça, yağışların yer alıına inme süresi arttığı için yüzeydeki göllenmeler artmaktadır. Sızma hızını etkileyen en önemli faktörlerden biri de toprak yapısıdır. Bu sebeple, çalışma alanına ait hidrolojik toprak grupları, ülkemiz genelinde üretilmiş olan toprak haritaları kullanılarak belirlenmiştir. Toprak haritalarındaki; büyük toprak grubu (BTG), toprak özellikleri kombinasyonu (TOK), diğer toprak özellikleri (DTO), arazi tipleri (AZT), diğer coğrafi veriler (DCV) ve şimdiki arazi kullanım şekli (SAK) verileri kullanılarak CBS yardımıyla hidrolojik toprak grupları elde edilmiştir (Özer, 1990). Çalışma alanına ait hidrolojik toprak grupları; A, B, C ve D zemin gruplarına göre renklendirilerek Şekil 8'de verilmiştir.

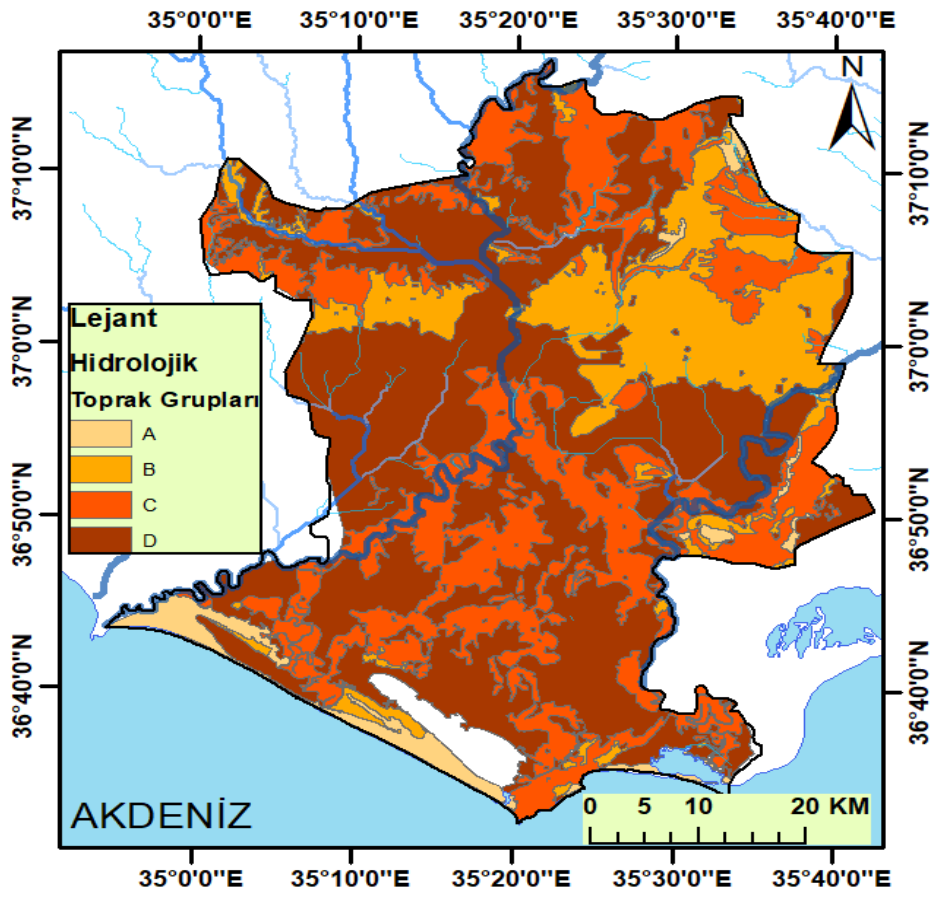

Şekil 8: Çalışma alanının hidrolojik toprak grupları haritası 
Zemin gruplarının belirlenmesi, özellikle yağış-akış ilişkisinin kurulması için oldukça faydalıdır. "A” grubu topraklar (düşük akış potansiyeli-iyi drenajlı); tamamen ıslanmaları durumunda bile orta infiltrasyon derecesine sahip, derin ve iyiden aşırıya kadar drene olmuş, başlıca kumlu ve çakıllı topraklardır. Bu topraklar yüksek su geçirme derecesine sahiptir. "B” grubu topraklar (normal akış potansiyeli-orta drenajlı); tamamen ıslanmaları durumunda orta infiltrasyon derecesine, orta derinden derine kadar derinliğe sahip, orta iyiden iyiye kadar drene olmuş, orta inceden orta kabaya kadar bünyeye sahip topraklardır. Bu topraklar orta derecede su geçirme derecesine sahiptir. "C" grubu topraklar (yüksek akış potansiyeli-düşük drenajlı); tamamen islanmaları durumunda yavaş infiltrasyon derecesine, orta inceden inceye kadar bünyeye ve yavaş infiltrasyon derecesine sahip topraklardır. Bu topraklar yavaş su geçirme derecesine sahiptir. "D” grubu topraklar (çok yüksek akış potansiyeli-çok düşük drenajlı); tamamen ıslanmaları durumunda çok yavaş infiltrasyon derecesine sahip, şişme potansiyeli yüksek killi topraklardır. Devamlı yüksek taban suyu seviyesine sahip topraklar, yüzeye yakın kil peni ya da kil katına sahip topraklar, hemen hemen geçirimsiz materyaller üzerindeki sığ topraklar bu gruba girer. Bu topraklar çok yavaş su geçirme potansiyeline sahiptir (Özer, 1990).

“A” grubu topraklar sızma hızı yüksek kum ve çakıllardan oluşurken, "D” grubu topraklar ise; sızma hızı çok düşük killi topraklardır (Tablo 2). Zeminin hidrolojik toprak gruplarının bilinmesi göllenme olabilecek yerlerin tespiti için de önemlidir.

Tablo 2: Zemin gruplarına göre son sızma hızları (Ağıralioğlu, 2004)

\begin{tabular}{cccc}
\hline Zemin Grubu & Sizma Potansiyeli & Zemin Cinsi & $\begin{array}{c}\text { Son Sızma Hızı } \\
(\mathbf{m m} / \mathbf{s a a t})\end{array}$ \\
\hline$A$ & Yüksek & Kum, çakıl & $7.5-12.5$ \\
\hline$B$ & Orta & Kumlu toprak & $3.8-7.5$ \\
\hline$C$ & Düşük & Killi toprak & $0.4-3.8$ \\
\hline$D$ & Çok Düşük & Kil & $0-0.4$ \\
\hline
\end{tabular}

\section{Uydu Görüntülerinin İşlenmesi}

Çalışmada, çözünürlüğü yaklaşık 10 m olan Sentinel-1 uydu görüntüleri kullanılmıştır. Sentinel-1, Avrupa Birliği tarafından Copernicus programı çerçevesinde üretilen 6 farklı uydudan (Sentinel-1, 2, 3, 4, 5 ve 5P) birisidir ve SAR sensörüne sahiptir. Son yıllarda SAR görüntülerinin kolaylıkla elde edilebilmesi ve SAR sensörlerinin artan geometrik çözünürlüğü sayesinde, radar ürünlerinin su ile kaplı alanların belirlenmesindeki kullanımı hızla artmaktadır. Su ile kaplı alanların mikrodalga saçılma mekanizmasında önemli avantajları vardır. Mikrodalga 1şını, su içeriği ve yüzey pürüzlülüğündeki farklılıklara duyarlıdır. Nem veya pürüzlülük artışı, geri saçılmanın artmasına neden olur. Genel olarak, SAR temelli arazi örtüsü ve bitki örtüsü haritalamasının sonuçları, kullanılan dalga boyu (X, C veya L bandı) ve veri polarizasyonuna (VV, HH, VH veya HV) bağlıdır (Mleczko \& Mróz, 2018). Sentinel-1 SAR C bandında ( $5.7 \mathrm{~cm}$ dalga boyu), tek (HH veya VV) ve çift $(\mathrm{HH}+\mathrm{VH}$ veya VV + VH) polarizasyona sahiptir. Son yıllarda sulak alanların izlenmesinde C bandının kullanımı artmaktadır (Kaplan ve Avdan, 2018b) ve bu çalışmada da Sentinel-1 SAR C bandı ve polarizasyon olarak VV modu kullanılmıştır.

Analiz edilecek görüntü tarihlerini belirlemek için, çalışma alanı ortasında yer alan ve en yüksek yağgşların ölçüldüğü Yüreğir/Çukurova Tarım Arş. İstasyonu'nun Aralık (2019) ve Ocak (2020) aylarındaki günlük toplam yağışlarına bakılmıştır (Şekil 9). Bu verilere göre; 09.12.2019 tarihli görüntü, referans olarak seçilmiştir. Seçim yapılırken; incelenen yağış periyodundan önceki bir tarih olmasına, öncesindeki bir haftaya kadar olan süreçte herhangi bir ciddi yağışın olmamasına, çalışma alanının tamamını kapsamasına ve grid formatında olmasına dikkat edilmiştir (URL-3).

Yağışlar sırasında ve sonrasında ise; 2, 8 ve 14 Ocak 2020 tarihlerindeki görüntüler incelenmiştir. Sonuç olarak; 1 adet olay öncesi 3 adet olay sırası ve sonrası olmak üzere 4 adet görüntü işlenerek ön incelemeden geçirilmiştir. 14 Ocak 2020 tarihli görüntüde yağışlardan kaynaklı göllenmelerin azaldığı gözlendiği için bu görüntü çalışmaya dâhil edilmemiştir. 


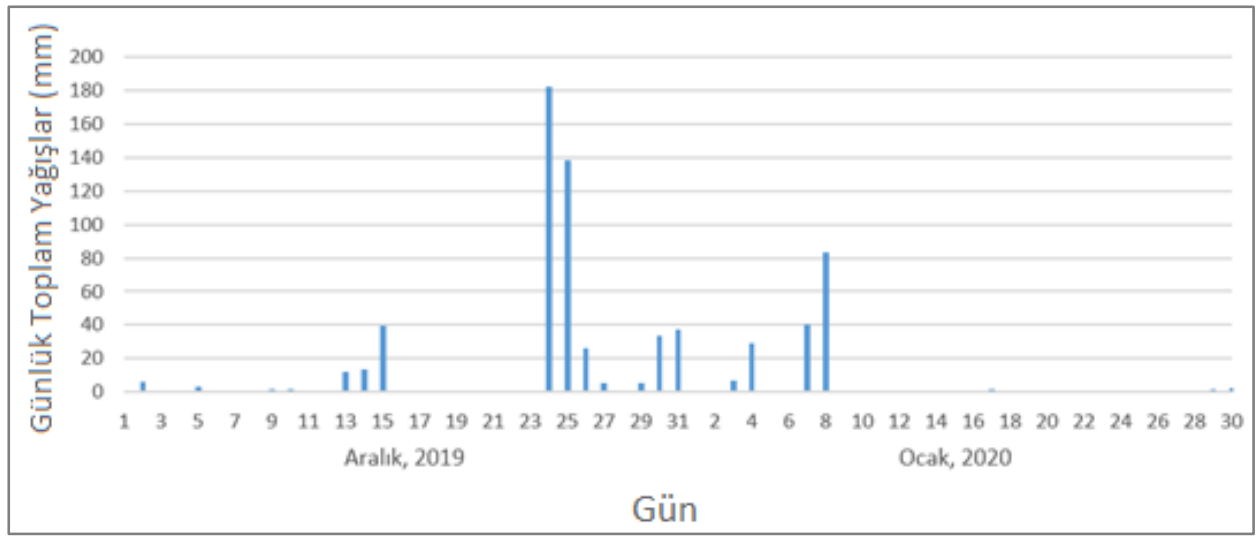

Şekil 9: Yüreğir/Çukurova Tarım Araştırma Istasyonu'nun iki aylık (Aralık, 2019 ve Ocak, 2020) günlük toplam yağışları

Görüntüleri işlemek için SNAP (Sentinels Application Platform) yazılımı kullanılmıştır. Çalışma kapsamında kullanılan görüntülere öncelikle düzeltme uygulanmıştır. Sonrasında görüntüler, çalışma alanına göre kestirilerek hem görüntülerin işlenme süresi hem de çıktı ürünlerin boyutunun küçülmesi sağlanmış, son olarak da görüntülerin radyometrik kalibrasyonları yapılmıştır.

Suyla kaplı alanların yansıma değerleri üzerinden analiz yapılarak bir eşik değer belirlemek üzere, bu alanlar üzerine yeterli sayıda örnek poligonu çizilmiştir. Çizilen poligonların ve tüm görüntünün 0.01 ile 0.06 değerleri arasındaki istatiksel ve görüntü analizleri yapılmıştır (Şekil 10). Bu analizler; hem tarım alanları üzerindeki göllenmelerde, hem de gerçek su kütlesi olan Seyhan Baraj gölünde yapılmıştır. Yapılan analizler sonucunda, eşik değeri 0.03 olarak belirlenmiş ve yansıma değeri 0.03 altında olan hücrelerin suyla kaplı oldukları kabulü yapılmıştır. Sadece suyla kaplı alanların görüntülerden çekilmesi maksadıyla yapılan işlem ("if Sigma0_VV $<0.03$ then 2 else NaN" kodu ile) sonrasında, suyla kaplı alanlar yani 0.03 'ten küçük değerli hücreler görünür hale gelmiştir.

Görüntü istenilen formatta dışarıya aktarılarak, görüntünün herhangi bir Coğrafi Bilgi Sistemi (CBS) yazılımı ile açılabilmesi sağlanmıştır. Yağış sonrasında kullanılan her iki görüntü de yağış öncesindeki referans görüntü ile elde edilen suyla kaplı alanlardan çıkartılmış ve yağışlardan kaynaklı oluşan suyla kaplı alanlar tespit edilmiştir. Burada renklendirilen suyla kaplı alanlar (02.01.2020), 01.01.2020 tarihli Sentinel-2 uydu görüntüsü (URL-4) ile örnek olarak iki bölgede karşılaştırılmış ve alınan sonuçların tutarlı olduğu gözlenmiştir (Şekil 11). Bu karş̧laştırmada Sentinel-2 uydu görüntüsü işlenmemiş ve yalnızca görsel olarak karşılaştırma yapılmıştır. Su birikintilerinin karşılaştırılması sonucu ortaya çıkan ufak farklılıkların, görüntüler arasındaki 1 günlük farktan kaynaklandığ düşünülmektedir. 


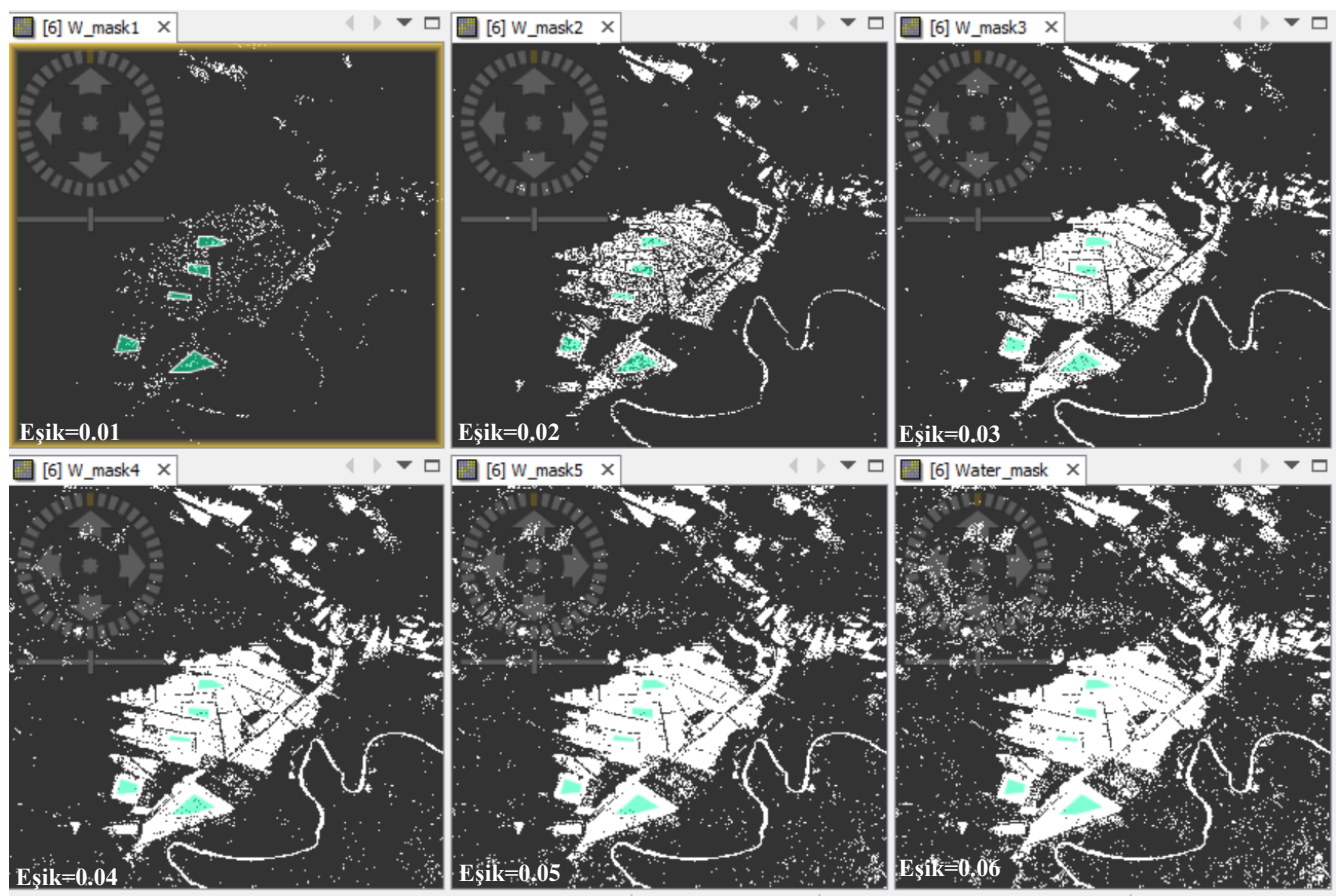

a) Tarım alanları üzerindeki göllenmelerdeki eşik değişimi

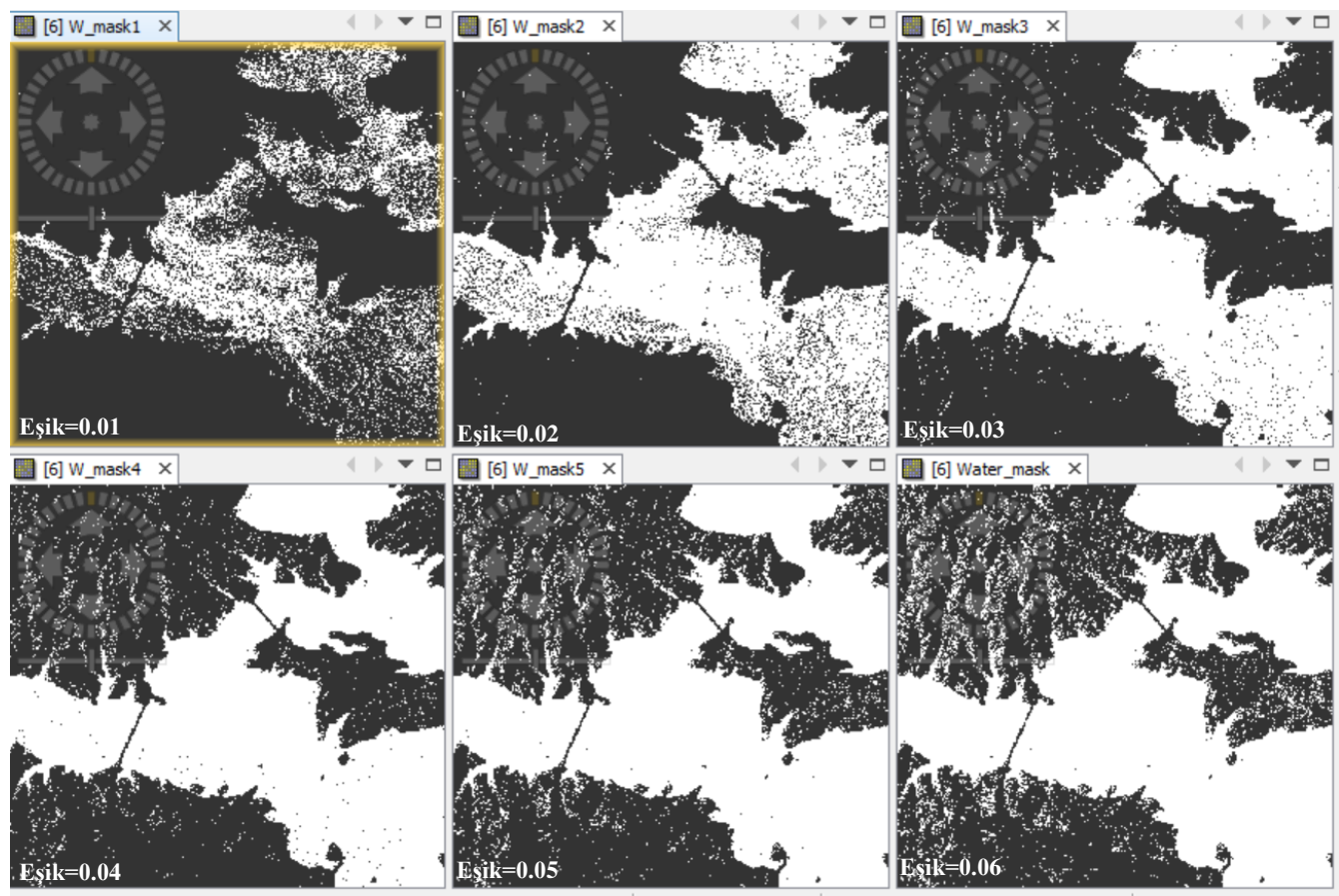

b) Baraj gölündeki eşik değişimi

Şekil 10: Tarım alanları üzerindeki ve baraj gölündeki eşik değişimleri (0.01-0.06 arası)
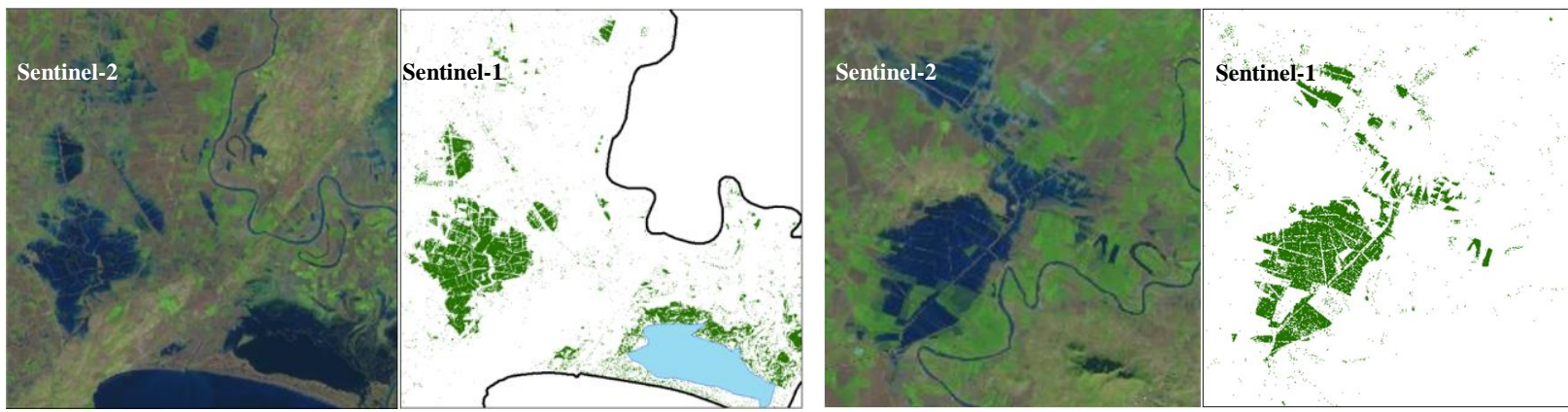

Şekil 11: Sentinel-2 görüntüsü (01.01.2020) ile Sentinel-1 görüntüsünün (02.01.2020) karşılaştırılması 


\section{Göllenen Bölgelerin Analizi}

Uydu görüntüleri kullanılarak işlenen görüntüler, CBS yardımıyla tekrar analiz edilerek yağışların sebep olduğu göllenmeler bulunmuştur. İncelenen tarihlerde ciddi yağışların gerçekleştiği, çalışma alanının kuzeyindeki Seyhan Baraj gölündeki alansal değişimde de net bir şekilde görülmektedir (Şekil 12). 9 Aralık 2019 (kırmızı), 2 Ocak 2020 (yeşil) ve 8 Ocak 2020'deki (mavi) su ile kaplı alanlar Şekil 12'de verilmiştir.

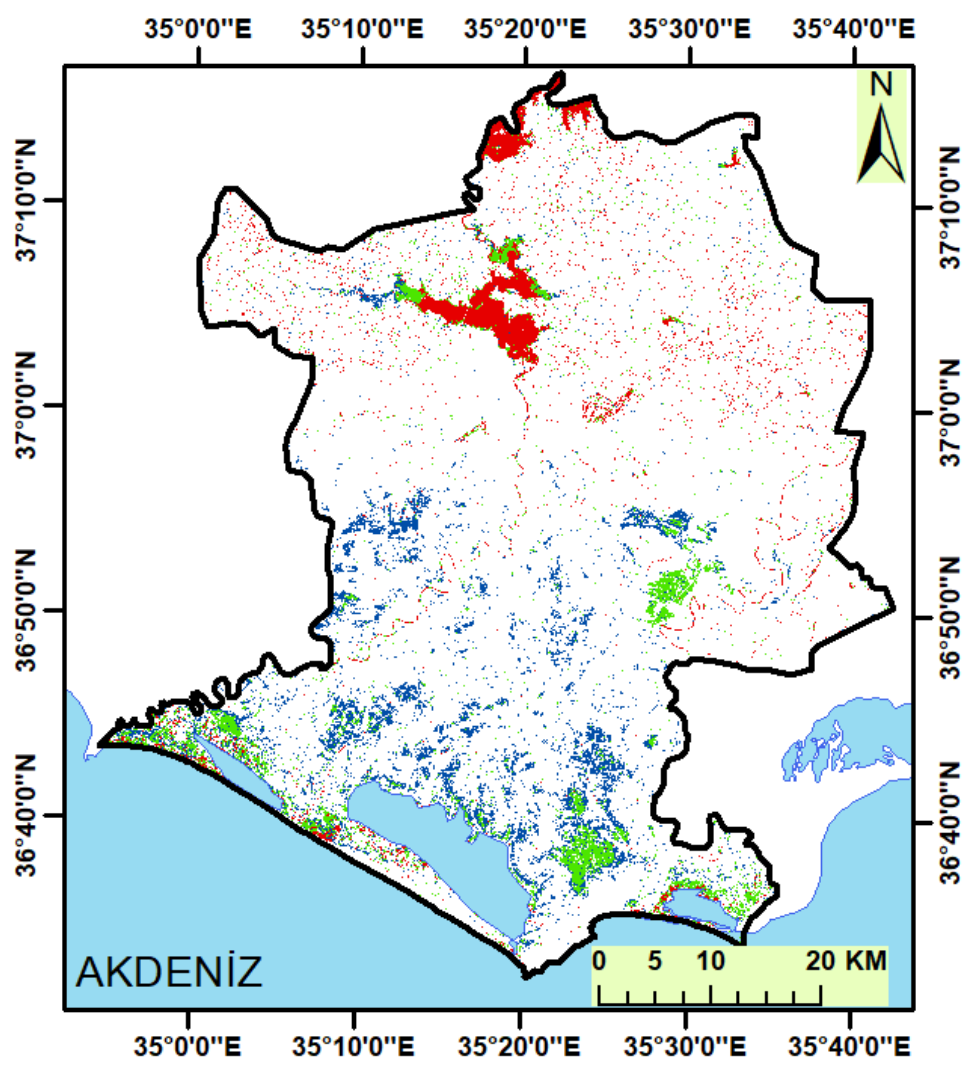

Şekil 12: Uydu görüntülerine göre göllenmeler

Tablo 3: Yaşanan göllenmelerin hidrolojik toprak gruplarına göre yüzdeleri

\begin{tabular}{ccc}
\hline & \multicolumn{2}{c}{ Göllenme (\%) } \\
\cline { 2 - 3 } $\begin{array}{c}\text { Hidrolojik Toprak } \\
\text { Grubu }\end{array}$ & $\mathbf{0 2 . 0 1 . 2 0 2 0}$ & $\mathbf{0 8 . 0 1 . 2 0 2 0}$ \\
\hline$C$ & 17 & 17 \\
\hline$D$ & 62 & 71 \\
\hline
\end{tabular}

\section{Sonuçlar}

Bu çalışmada; Adana ili ve civarında, 24.12.2019 - 08.01.2020 tarihleri arasında gerçekleşen ve 16 günlük periyotta 594 mm’ye, 3 günlük periyotta 346 mm’ye, günlükte ise 182 mm’ye kadar ulaşan yağışlar analiz edilmiştir. Söz konusu yağışlar hem yerleşim yerlerinde hem de tarım alanlarında maddi zararlara sebep olmuştur. Yağışların olumsuz etkileri Devlet Su İşleri Genel Müdürlüğü ve Meteoroloji Genel Müdürlüğü tarafından hazırlanan taşkın raporlarında da görülmektedir (URL5 ve URL-6).

Noktasal OMGİ verilerinden üretilen alansal yağışlarla gerçekleştirilen bu çalışma, uydu ve radar yağış ürünleri kullanılarak da benzer şekilde yapılabilir. Üretilen yağış verileri ile yapılan toprak nemi karşılaştırmalarında, yağışların yoğun olarak gerçekleştiği bölgelerdeki toprak neminin daha fazla arttığ gözlenmiştir. İnceleme yapılan 16 günlük periyotta, toprak 
nemindeki artışın \%210’a kadar ulaştığı bölgeler gözlenmiştir. Yağışların en etkili olduğu 24.12.2019 tarihinde ise bu artışın, \%170'e kadar çıktığı tespit edilmiştir. Toprak neminde gerçekleşen bu artışlar, toprak yapısı ve eğime de bağlı olarak göllenmelere sebep olmuştur. Burada yapılan günlük analizlere ek olarak, özellikle toprak nemi değişiminin daha iyi analiz edilebilmesi için, verinin temin edilebildiği 6 saatlik periyotlarda da inceleme yapılabilir. Çalışmada kullanılan SMAP verisi yaklaşık 9 km çözünürlüğe sahiptir. Bu çözünürlük, büyük alanları etkileyen sistem yağışlarındaki çalışmalarda yeterli olabilir ancak lokal yağışlar ve ufak çalışma alanları için yeterli gelmeyecektir. Burada sağlanan veride toprağın ilk $5 \mathrm{~cm}$ 'lik kısmı için analizler yapılmıştır. Gelecekteki çalışmalarda, toprağın daha alt katmanlarından sağlanan toprak nemi verileri ile de farklı analizler yapılabilir ve ortaya çıkan farklar tartışılabilir.

Su ile kaplı alanları tespit edebilmek için yapılan çalışmada, yağışlar öncesindeki 09.12.2019 tarihli görüntü ile yağışlar sırasındaki 02.01.2020 ve sonrasındaki 08.01.2020 tarihli Sentinel-1 SAR uydu görüntüleri kullanılmıştır. Yağışlar sırasında ve sonrasındaki su kaplı alanlardan, 09.12.2019 tarihindeki su kaplı alanlar çıkartılarak gerekli analizler yapılmıştır. Yapılan analizler sonucunda, uzaktan algılama ürünleri kullanılarak ve CBS yardımıyla su kaplı alanların tespit edilebildiği görülmüştür. İleriki çalışmalarda; Sentinel-2, Landsat-8 vb. farklı uydu görüntüleri kullanılarak veya çalışmada kullanılan VV bandının yanında diğer bantlar (HH veya çift bantlar) da kullanılarak analizler yapılabilir.

Aşırı yağışlar sebebiyle oluşan göllenmelerin çok büyük bir kısmı; çalışma alanının güney kısmında, özellikle eğimin düşük olduğu ve kil içeriğine sahip olan bölgelerde meydana gelmiştir. Yapılan analizlere göre; göllenmelerin yaklaşık \%92'sinin, \%1 ve altında eğime sahip tarım alanlarında gerçekleştiği tespit edilmiştir. Bu duruma tabii ki yağış lokasyonu ve toprak yapısının da etkisi vardır ancak yine de göllenmeler için eğimin çok önemli bir etken olduğu söylenebilir.

Göllenmelerin araştırıldığg 02.01.2020 ve 08.01.2020 tarihli görüntü analizlerine göre; hidrolojik toprak grupları baz alınarak yapılan incelemelerde göllenmelerin alansal olarak sırasıyla; \%79 ve \%88'inin “C grubu (Killi toprak)” veya "D grubu (Kil özelliği taşıyan)” topraklarda gerçekleştiği tespit edilmiştir. Yapılan bu tespit; topraktaki kil içeriğinin, göllenmedeki önemini ortaya çıkarmıştır. Buradaki göllenmelerin daha detaylı analizi için; drenaj kanallarının lokasyonlarının ve kapasitelerinin yanı sıra bölgedeki taban suyu haritalarından da faydalanılabilir.

Sonuç olarak bu çalışmada; Sentinel-1 SAR uydu görüntüleri işlenerek, şiddetli yağışlardan kaynaklı göllenmeler tespit edilmiştir. Ayrıca Sentinel-1 SAR uydu görüntüleri ile çalışmaya konu olan yağış, toprak nemi, eğim ve hidrolojik toprak grubu verilerinin entegrasyonu sağlanmış ve gerekli analizler yapılarak göllenmelerin sebepleri tartışılmıştır. Tarım alanlarındaki göllenmelerin uydu görüntüleri ile tespit edilebildiği ve bu göllenmelerin yağış lokasyonu ve yağışlara bağlı olarak artan toprak nemi ile birlikte eğim ve toprak yapısına da bağlı olduğu sonucuna varılmıştır. Burada kullanılan yöntemlerin özellikle taşkına maruz kalan alanların tespiti için de oldukça önemli olduğu düşünülmektedir.

\section{Teşekkür}

Çalışmalarımızda bize desteğini hiç eksik etmeyen Tarım ve Orman Bakanlığı Su Yönetimi Genel Müdür Yardımcısı Mustafa UZUN'a teşekkür ederiz.

\section{Yazar Katkısı}

Salih Babagiray: Fikir, Tasarım, Literatür taraması, Veri toplama ve işleme, Analiz ve yorumlama, Yazım. Kaan Kalkan: Fikir, Denetleme, Yazım, Makale değerlendirme. 


\section{Çıkar Çatışması Beyanı}

Yazarlar, bu çalışmada bilinen ilgili herhangi bir finansal veya finansal olmayan çıkar çatışması olmadığını beyan eder.

\section{Kaynaklar}

Ağıralioğlu, N. (2004). Taşkın Hidrolojisi Çalışmaları. IV. Ulusal Hidroloji Kongresi, Hidrolojide Yeni Yöntemler Semineri, İstanbul. 122.

Akgül, M. A. (2018). Sentetik Açıklıklı Radar verilerinin Taşkın Çalışmalarında Kullanılması: Berdan Ovası Taşkını. Geomatik, 3(2), 154162.

Akgül, M. A., \& Çetin, M. (2019). Tarımsal Drenaj Alanlarında Meydana Gelen Taşkınlar Ve Etki Alanlarının Uzaktan Algılama İle Belirlenmesi: Aşağı Seyhan Ovası Alt Havzasında Örnek Bir Çalışma. 10. Ulusal Hidroloji Kongresi 2019, 849.

Bulut, B., Yilmaz, M. T., Afshar, M. H., Sorman, A. U., Yucel, I., Cosh, M. H., \& Simsek, O. (2019). Evaluation of remotely-sensed and model-based soil moisture products according to different soil type, vegetation cover and climate regime using station-based observations over Turkey. Remote Sensing, 11(16), 1875.

Carreño Conde, F., \& De Mata Muñoz, M. (2019). Flood monitoring based on the study of Sentinel-1 SAR images: The Ebro River case study. Water, 11(12), 2454.

Chen, F. W., \& Liu, C. W. (2012). Estimation of the spatial rainfall distribution using inverse distance weighting (IDW) in the middle of Taiwan. Paddy and Water Environment, 10(3), 209-222.

Entekhabi, D., Njoku, E. G., O’Neill P. E., Kellogg, K. H., Crow, W. T., Edelstein, W. N., Entin, J. K., Goodman, S. D., Jackson, T. J., Johnson, J., Kimball, J., Piepmeier, J. R., Koster, R. D., Martin, N., McDonald, K. C., Moghaddam, M., Moran, S.,Reichle,R., Shi, J. C., Spencer, M. W., Thurman, S. W., Tsang, L. \& Zyl J. V. (2010). The Soil Moisture Active and Passive (SMAP) Mission. Proceedings of the IEEE, 98(5), 704-716.

Kaplan, G., \& Avdan, U. (2018a). Sentinel-1 Verileri Kullanılarak Sulak Alanların Aylık Periyotlarla Takip Edilmesi. VII. Uzaktan Algilama ve CBS Sempozyumu, Eskişehir. 2.

Kaplan, G., \& Avdan, U. (2018b). Monthly analysis of wetlands dynamics using remote sensing data. ISPRS International Journal of GeoInformation, 7(10), 411.

Ly, S., Charles, C., \& Degré, A. (2013). Different methods for spatial interpolation of rainfall data for operational hydrology and hydrological modeling at watershed scale: a review. Biotechnologie, Agronomie, Société et Environnement, 17(2), $392-406$.

Manjusree, P., Kumar, L. P., Bhatt, C. M., Rao, G. S., \& Bhanumurthy, V. (2012). Optimization of threshold ranges for rapid flood inundation mapping by evaluating backscatter profiles of high incidence angle SAR images. International Journal of Disaster Risk Science, 3(2), 113-122.

Mleczko, M., \& Mróz, M. (2018). Wetland mapping using sar data from the sentinel-1a and tandem-x missions: A comparative study in the biebrza floodplain (Poland). Remote Sensing, 10(1), 78.

Özer, Z. (1990). Su yapılarının projelendirilmesinde hidrolojik ve hidrolik esaslar. Köy Hizmetleri Genel Müdürlüğü, Havza Islahı ve Göletler Daire Başkanlı̆̆l, Ankara. 378 - 380.

Pitt, R., Chen, S. E., Clark, S. E., Swenson, J., \& Ong, C. K. (2008). Compaction's impacts on urban storm-water infiltration. Journal of Irrigation and Drainage Engineering, 134(5), 652-658.

Rahman, M., Di, L., Yu, E., Lin, L., Zhang, C., \& Tang, J. (2019). Rapid flood progress monitoring in cropland with NASA SMAP. Remote Sensing, 11(2), 191.

Smith, L. C. (1997). Satellite remote sensing of river inundation area, stage, and discharge: A review. Hydrological processes, 11(10), $1427-1439$.

Tavus, B., Kocaman, S., Gökçeoğlu, C., \& Nefeslioğlu, H. A. (2018). Considerations on the use of Sentinel -1 Data in flood mapping in urban areas: Ankara (Turkey) 2018 Floods. International Archives of the Photogrammetry, Remote Sensing \& Spatial Information Sciences.

Usul, N. (2008). Mühendislik Hidrolojisi (pp. 149-152). ODTÜ Yayınc1lık

URL-1: NASA, SMAP veri taban1, https://smap.jpl.nasa.gov/faq/, (Erişim Tarihi: 17 Kasım 2020) 
URL-2: NASA Verileri (Earth Data, NASA), https://search.earthdata.nasa.gov/search/, (Erişim Tarihi: 26 May1s 2020).

URL-3: Avrupa Birliği, Kopernikus Programı Açık Veri Tabanı (Copernicus Open Access Hub, EU), https://scihub.copernicus.eu/, (Erişim Tarihi: 26 Mayıs 2020).

URL-4: Amerika Birleşik Devletleri Jeolojik Araştırma Kurumu (United States Geological Survey, USGS), https://glovis.usgs.gov/, (Erişim Tarihi: 26 Mayıs 2020).

URL-5: Devlet Su İşleri Genel Müdürlüğü, Taşkın Raporu, http://tambis.dsi.gov.tr/, (Erişim Tarihi: 19 Haziran 2020).

URL-6: Meteoroloji Genel Müdürlüğü, Fevk Raporu, https://mevbis.mgm.gov.tr/, (Erişim Tarihi: 19 Haziran 2020). 